\title{
口需血管筋腫の光学顕微鏡および電子顕微鏡による観察
}

岡田由美 - 亀山洋一郎 - 大坪義和 - 竹花茂樹

河 合 幹*・竹原督之輔*・山田祐 敬*

\section{Light and electron microscopic observations of the lip angiomyoma}

\author{
Yoshimi Orada $=$ Yoichiro Kameyama Yoshikazu Ohtsubo . Shigeki Takehana \\ Tsuyoshi KAwAI* . Tokunosuke TAKEHARA* . Yutaka YAMADA*
}

\section{緒}

\section{言}

口腔領域に発生する血管筋腫は非常に少ない，最近わ れわれは，口唇部に発生した血管筇庫の 1 例を，光学影 微鏡および電子顕微鏡により観察する機会を得たので, その概要を報告する。

\section{症}

例

\section{患 者： 52歳 男性. \\ 初 猃：昭和 52 年 8 月 $\square$. \\ 主 訴：下口唇部の無痛性腫瘤.}

\section{家族歴および既往歷：特記事項なし.}

現病歴：約13年前より,下口唇部の粟粒大の董瘤に気 がついていたが，自発痛などがないため放置した，以後， 腫瘤の増大を自覚せずに経過した。昭和52年 7 月中旬, ら蝕の治療のため，某歯科医院を受診した際，下口唇部 の腫瘤を指摘され，昭和52年 8 月 腔外科に来院した。

現 症：全身的には，体格は中等度，栄養状態は良好 で，特記すべき事項はない，局所的には，左側下口辰部 に, 表面は正常色, 境界は明膫, 可動性で弾性軟の無痛 性腫瘤を認めた。所属りンパ節の腫脹はみられなかっ た。また口腔内所見は正常であった。

爱知学院大学㴹学部病理学教室（主任：福島万寿 雄教授)

* 愛知学院大学歯学部第 2 口腔外科学教室（主任 : 河合 幹教授)

Department of Pathology, School of Dentistry, Aichi-Gakuin University (Chief: Prof. Masuo Fukushima)

* Second Department of Oro-Maxillo-Facial Surgery, School of Dentistry, Aichi-Gakuin University (Chief: Prof. Tsuyoshi Kawai)

受付日：昭和53年11月13日

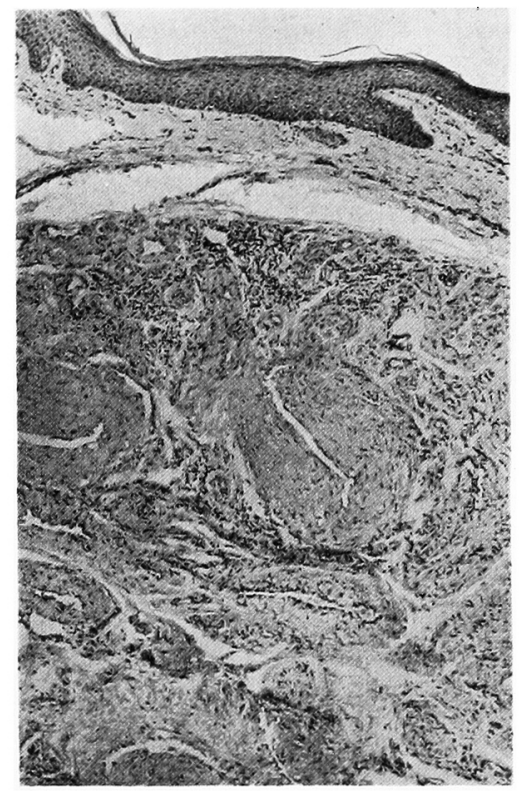

图 1 睡瘍は周囲の組織と線䧽組織で境界さ れ，内部には壁の肥厚した血管が多数 みられる。（H.E. 染色， × 40)

臨床検查所見：血 液，尿 等の諸検査に特に異常はな かった。

臨床診断：粘液襄胞（のち手術材料から病理組織学的 には，血管筋腫と診断された）。

手術所見 臨床診断のもとに, 下口唇の連瘤摘出を行 った。術後 1 年 2 か月を経た現在, 再発はみられず，経 過は良好である。

摘出物肉眼的所見: 擔出物は, $0.8 \times 0.8 \times 0.6 \mathrm{~cm}$ の

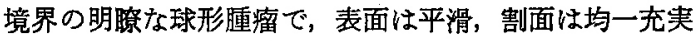
性で, 帯黄白色を呈していた，粘液変性，石灰変性，壊 死などは，内部に認められなかった。

病理組織学的検索方法：切除腫場組織は, 光学顕微鏡 用には，10\%ホルマリン溶液固定後，通法に従い，ハラ 


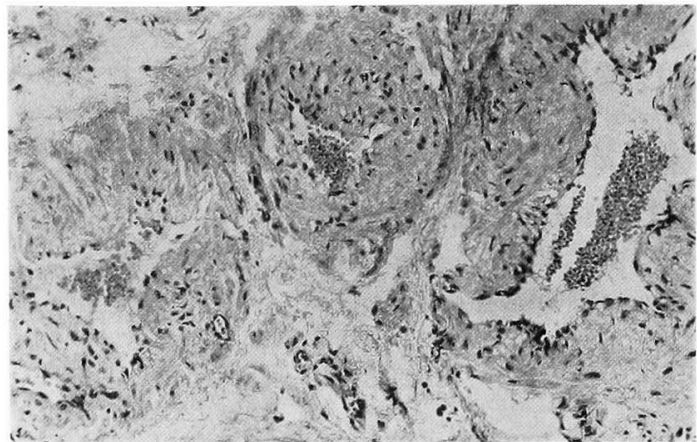

図 2 厚い壁に囲まれた血管空は大小不同で，星状 形をなしている。（H.E. 染色， ×100)

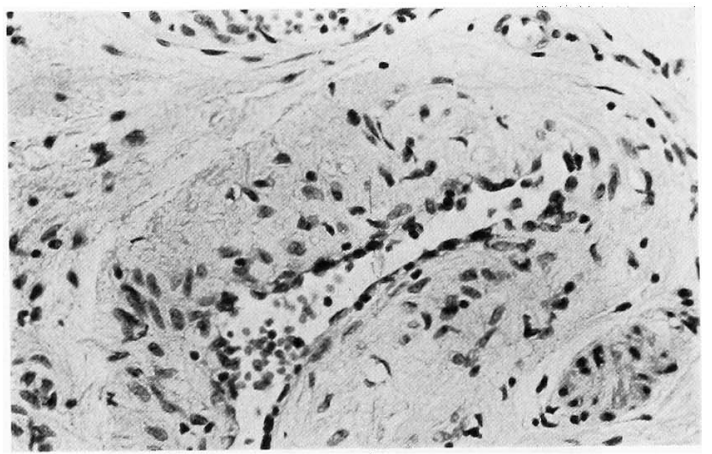

図 3 血管壁の内面には立方形あるい情円形の内 皮様稩胞の被覆がみられ，血管壁には棈円形 あるいは紡鍍形の平滑筋様細胞が認められ る. (H.E. 染色, ×200)

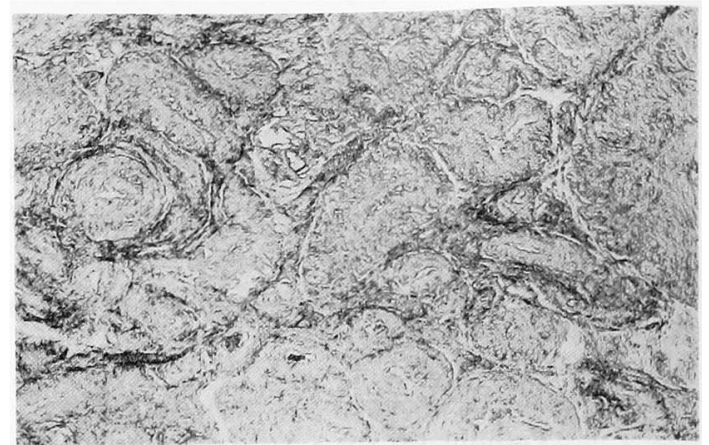

図 4 血管壁は陽性を示す。(P.T.A.H. 染色， $\times 40$ )

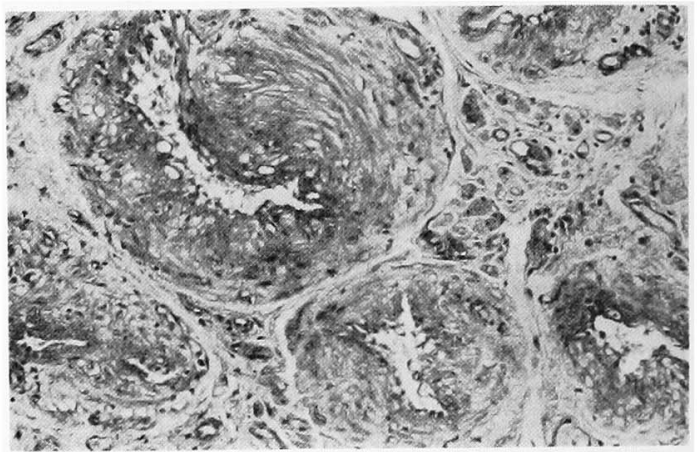

图 5 血管は結節状になり，間質との境界は明眭で ある（PAS 染色， ×100）

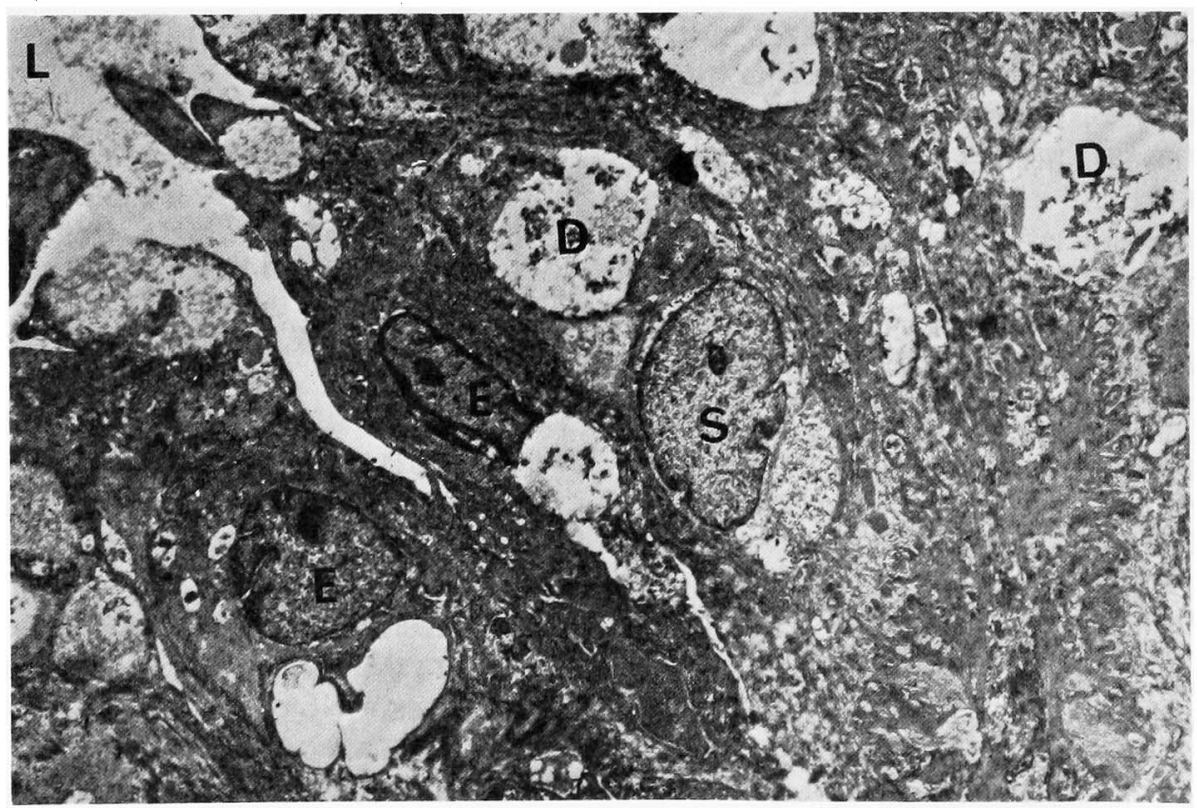

图 6 内皮棬細胞々平滑筋様和胞がみられる。( $(\times 2,500)$ 


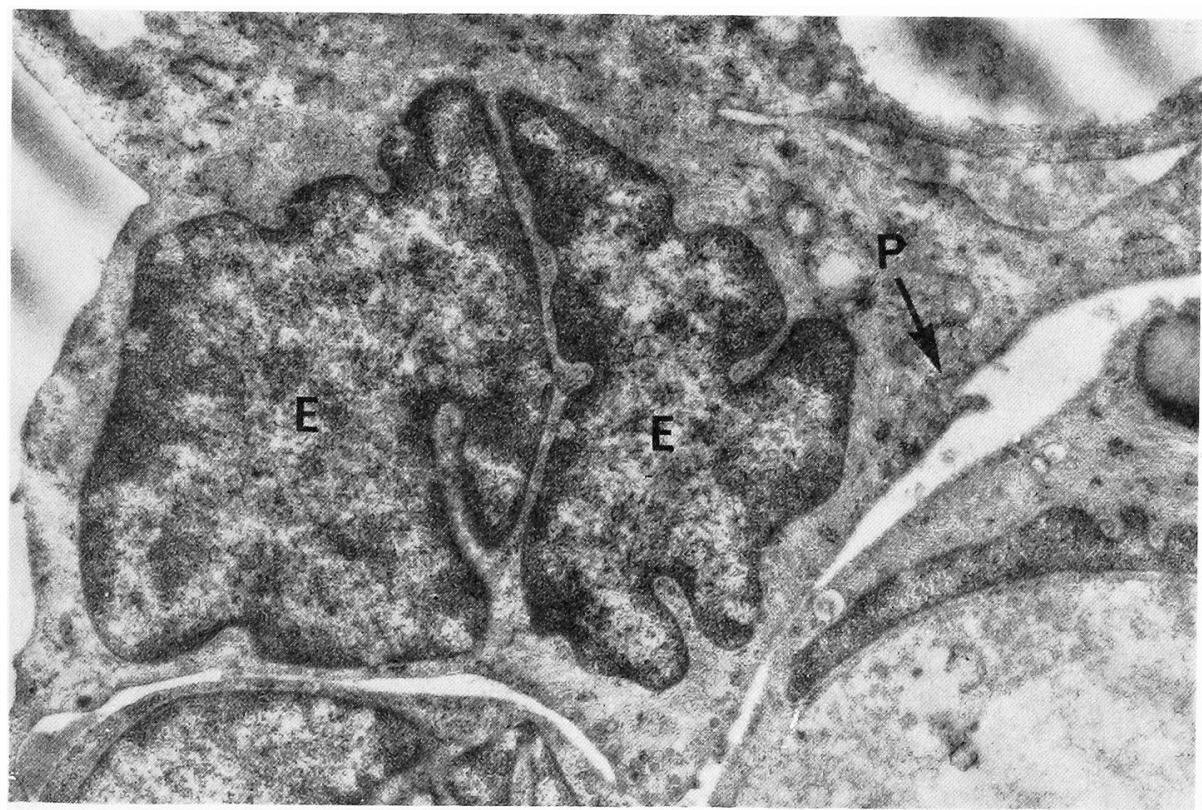

図 7 内皮様細胞の核膜は凹凸不整で，湅胞質には豊富な勫線維と拎小胞がみられる。 $(\times 9,500)$

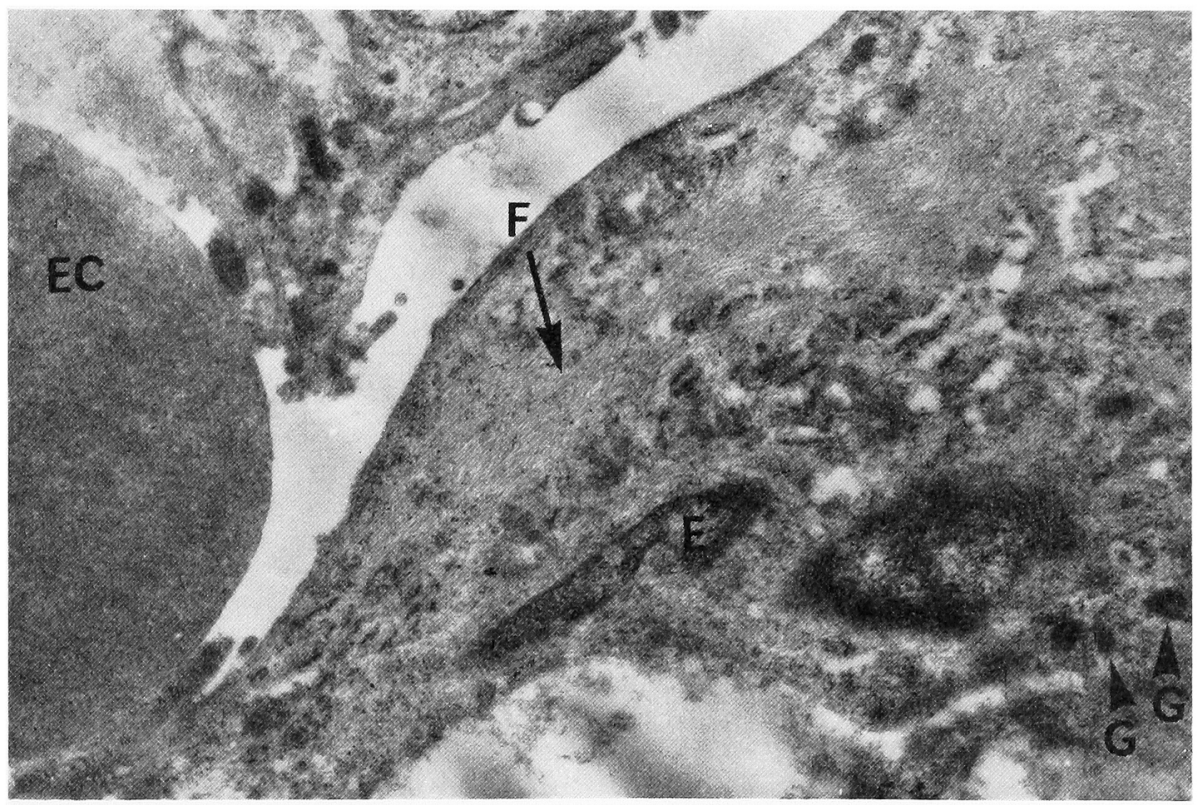

図 8 内皮様細胞には豊富な細線維と䉓子密度の高い顆粒が存在する。 $(\times 8,500)$

フィンに包埋し， $4 \mu$ の切片標本を作り，へマトキシリ ン・エオジン染色，エラスキカ・ワンギーソン染色, P.T.A.H. 染色，マッソン染色，アザン・マロリー染色， PAS 染色，アルシアン・ブルー染色を施して鏡検した. 笔子顕砫鏡用としては，切除後10\%ホルマリン溶夜に浸
した尰瑒組織をカコジレート緩衝液にて一冝夜洗い, 緩 衝 $1 \%$ オスミウム酸にて 2 時間後固定し，その後上昇了 ルコール系列脱水を通し，Epon 812 に包埋した，次い で超薄切片を作製し，ウラニール・鉛二重染色を行い， J.E.M. 7T. 型電子顕徽鏡で観察した。 


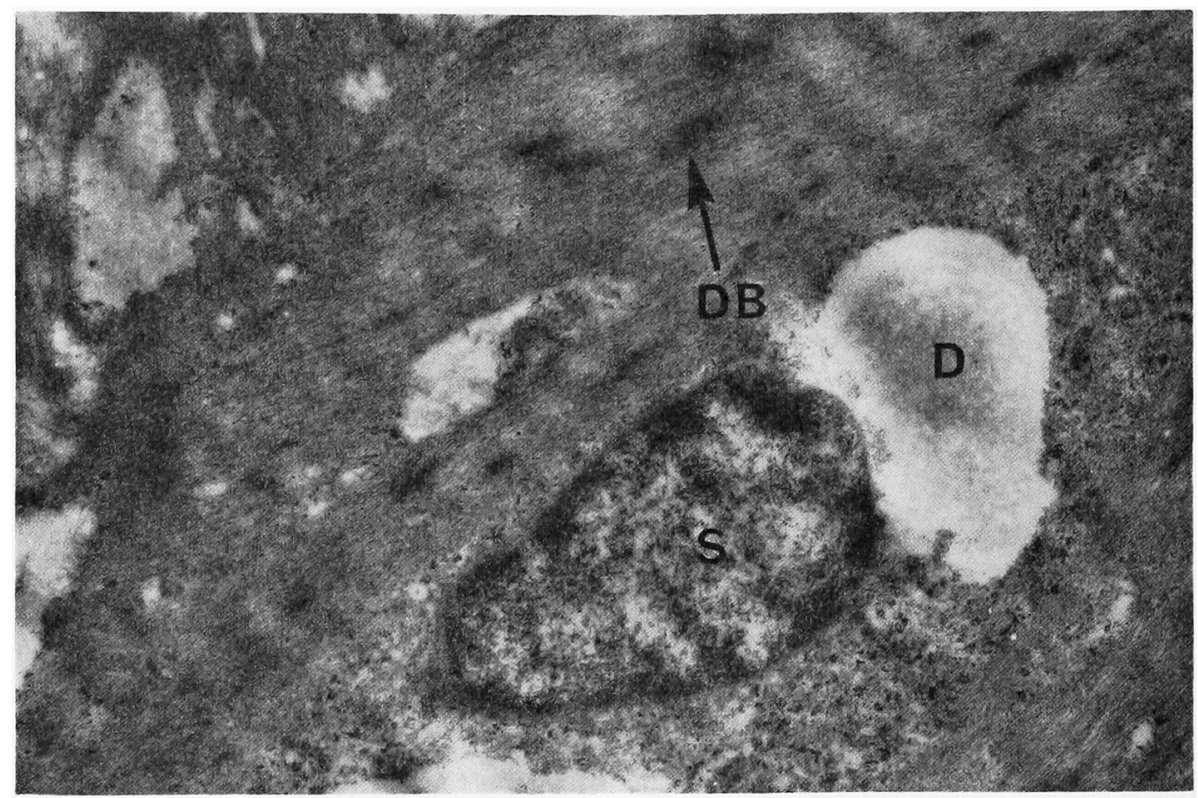

图 9 平滑筋様細胞には筋フィラメントと縹密体がみられる。核周包部には小器官が存在している. $(\times 9,500)$

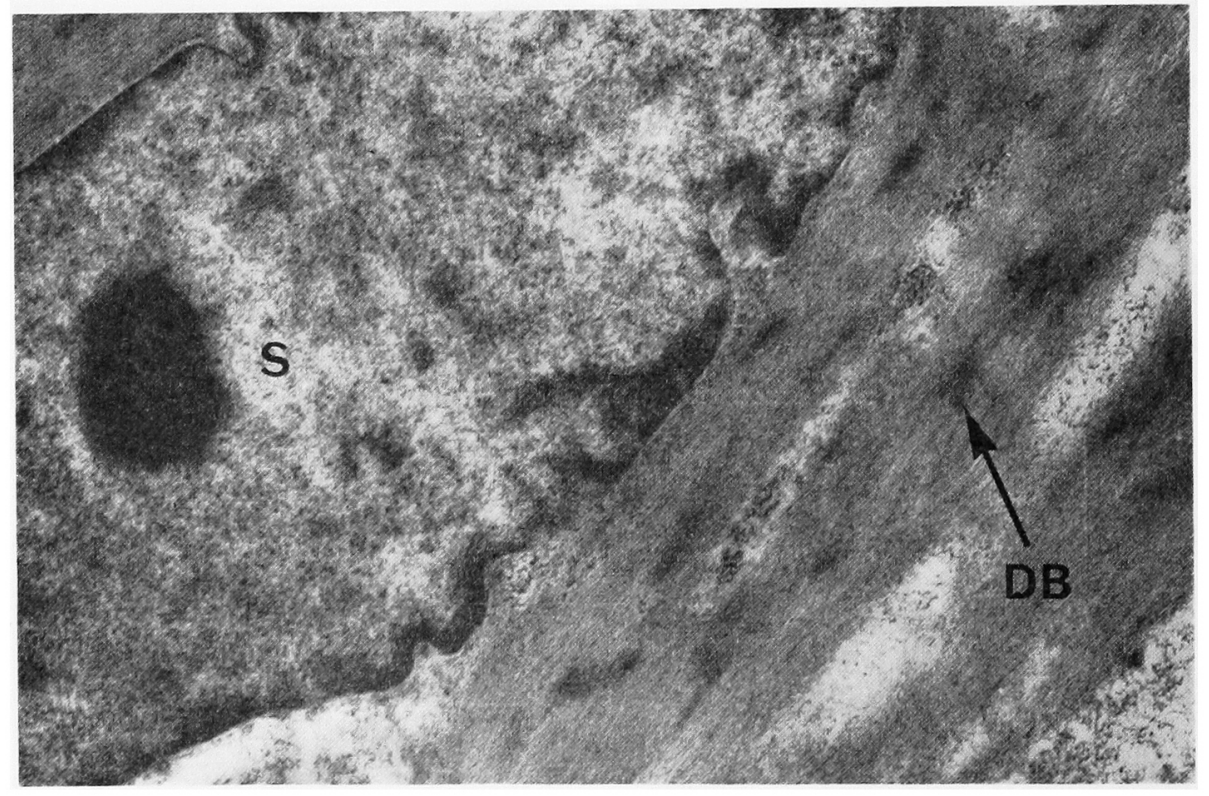

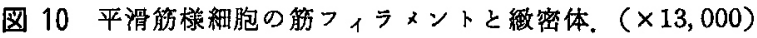

光学影微鏡所見：ヘマトキシリン・エオジン染色で は，腫湯組峨は周囲と境界が明瞭で，内部には壁の肥厚 した血管を多数形成していた（图 1 ），血管腔は大小不 同の細長い裂状あるいは星状の形を示し，管腔の内面は 主として立方形の内皮様細胞で被覆されていた（図 2,
3).また血管腔内は血球で満たされているものむあった。 皿管壁は結節状に増殖した筋組織と線維珄組織で構成さ れ，平滑䇗様細胞は多角形あるいは紡錘形であった（图 3．これらの平滑筋様細胞はこの腫場の主体をなしてい た。細胞には核の異型性，核分裂像等は想められなかっ 


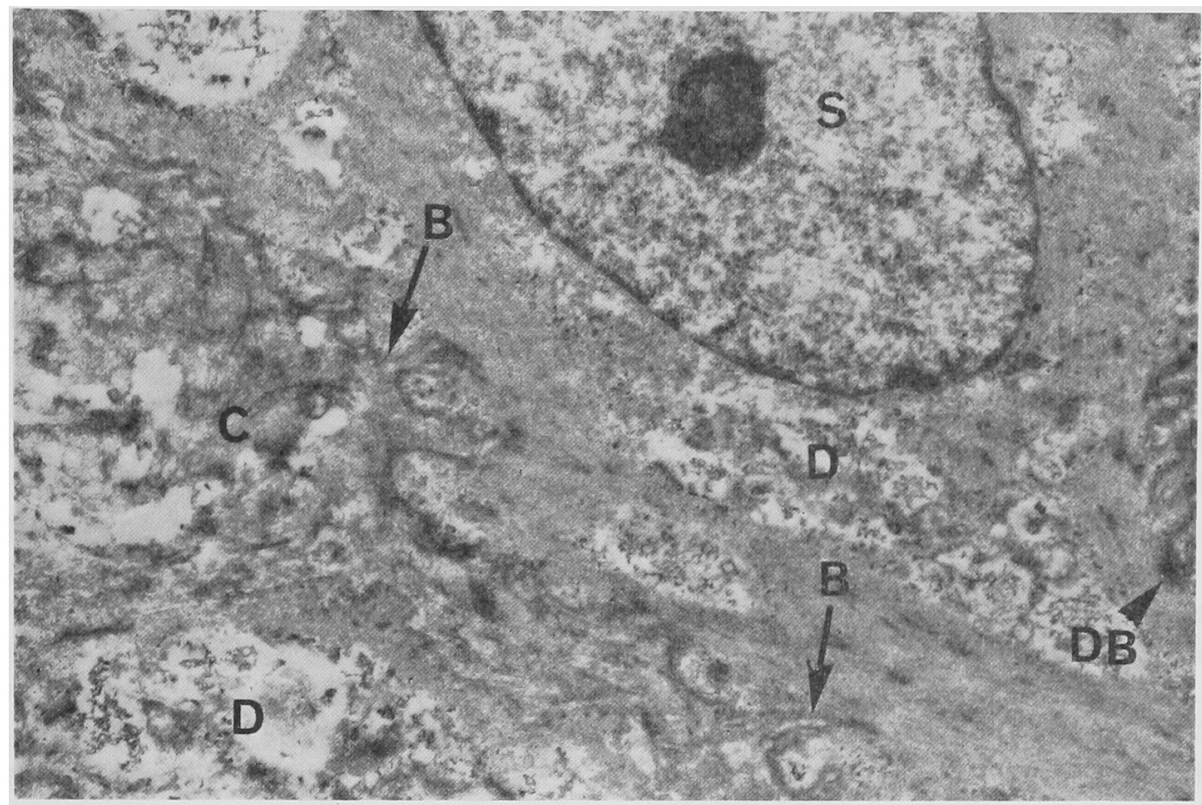

図 11 平滑筇様細胞の細胞膜の内側には䋊密体がみられ，その外側には基底膜がみられる。また， 間質には膠原線維が存在している。 $(\times 7,500)$

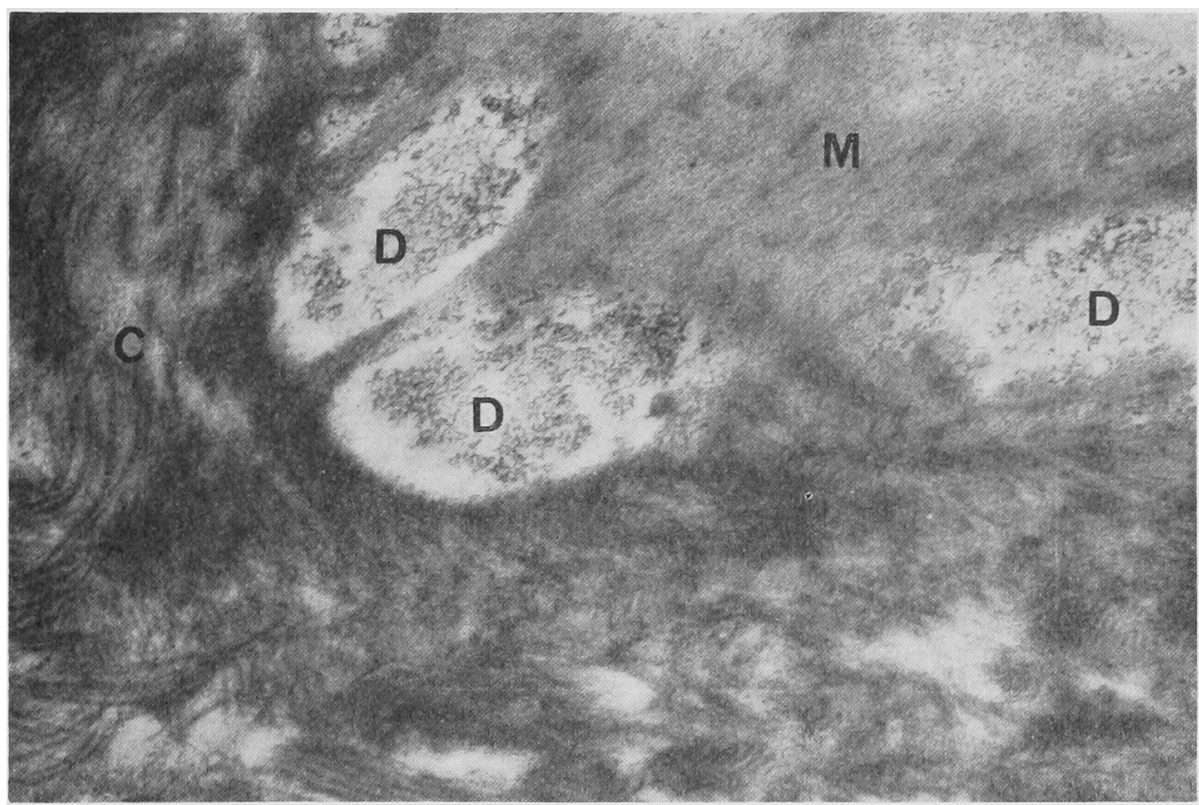

図 12 間質には泟原線維がみられる。( $(\times 10,000)$

$\mathrm{L}$ ：血管腔， $\mathrm{E}$ ：内皮様勫胞の核， $\mathrm{S}:$ 平滑筋様稩胞の核， D：ホルマリン固定によると考えられる

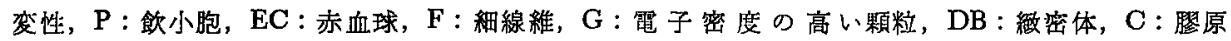

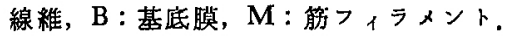


た. 全体的に腫湯の間質は少なく，線維芽細胞もあまり みられなかった。

エラスチカ・ワンギーソン染色, P.T.A.H. 染色で は，血管壁に筋線維を示す染色性がみられた（図 4). マッソン染色とアザン・マロリー染色では，間質の膠原 線維が陽性に染色された。 PAS 染色では，血管壁は弱 陽性を示し，また腫瘍組織と間質の境界は明瞭であっ た（図 5 ).アルシアン・ブルー染色では，血管壁は弱 陽性を示した。

電子顕微鏡所見：血管の内面を被覆する内皮様細胞は 主として立方形で，細胞質内が空胞状にぬけているのが 散在性に認められた (図 6). 内皮様細胞のミトコント リア, 粗面小胞体, ゴルジ体などの細胞小器官の発達は 普通であるが, 細線維 (fine filament) は比較的豊富 で，核膜に並行して存在し，細胞膜周囲には豊富な飲小 胞 (pinocytotic vesicle) がみられた（図 7)。また，細 胞質中に電子密度の高い顆粒を多く含んた細胞もみられ た（図 8). 核は緗胞の中央に位置し，その外形は細胞 形態に類似して楕円形ないし即円形のものが多く，核膜 は凹凸不整で陷凹を示すものがほとんどであった。核小 体は核の中央部に通常 $1 \sim 2$ 個認められた。血管内腔に 接する細胞膜には微䋐 毛 (microvilli) が割と少なく, また，隣接細胞とは少数の密着結合 (tight junction)に よって結合していた。

血管壁を構成する平滑㘯様細胞は多角形ないし紡鍾形 で，この腫汪の主体をなしていた（図 9). 平滑筋様細 胞の細胞小器官は核周辺部の細胞質に存在しているが,

発達はあまりよくなかった。 また，グリコーゲン顆粒は 量の差はあるが，ほとんどの細胞質内でみられた（図 9). 細胞内小器官の存在する部分より外側の細胞質周辺 部には，散在性に緻密体 (dense body) を伴う多数の筋 フィラメント (myofilament) が細胞の長軸方向に走って いた(図 9，10）。平滑筋様細胞のほぼ中央部に核は位置 し，外形は細胞形態に相似していた．核小体は中央部に 1 個みられた，核膜はなめらかなものから凹凸不整のも のまでみられたが，深い陥凹を示すものは一般に少なか った（図 10）。また，緻密体は細胞膜の内側にそって散 在性に存在していたが，細胞膜の内側には明膫な飲小胞 はあまり認めなかった（図 11）。細胞膜の外側に密接し て基底膜がみられ，この基底膜に付着するようにして膠 原線維が細胞間隙に介在していた（図 12）。間質には， 光学顕微鏡所見と同じよらに線維芽細胞はあまりみられ なかった。

\section{考}

案

血管笳腫は口腔領域ではまれで，わが国と欧米で現在 までに約 30 例の報告がみられるにすぎない1,2)，本腫痬 は年龄的に 40〜60 歳の人に発生し，性別では女性に多
いといわれている1)。好発部位は, 口唇, 口蓋, 舌, 煩 粘膜，歯肉などである，本症例の患者は男性であった が，年齢および発生部位では今までに報告されたものと 一致している.

臨床的に，血管筋腫と診断された例は少なく，線維 腫, リンパ管腫, 粘液蒛胞なとと診断された例が多

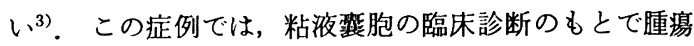
の摘出手術を受け, その後の摘出物の病理組織学的検査 で血管筋腫と診断されたものである．このように臨床的 な所見のみでは, 本腫瘍の診断は困難と考えられる.

血管筋腫の組織学的検索は少なくないが，電子顕微鏡 学的検索についての論文は, われわれの知るかぎりで は, Reichart らの報告の 1 (列だけである ${ }^{4)}$.この腫痬の組 織学的な特徵は, 腫湢と周囲の結合組織との境界が明瞭 で，腫瘍内には大小の円形ないし星状形の血管腔が多数 みられ，その周囲に平滑筋線維が同心円状あるいは結 節状に增殖し，それらが互いに連なったり離れたりしな がら集団的に存在していることである ${ }^{5)}$. 森本 ${ }^{6)}$ は，血管 筋腫を血管の組織学的形態と平滑筋線維によって, 次の 3 つの型に区別している. 第 1 の型は，毛細管に相当す るものが多く，血管腔は小さいか狭く裂隙状を示し，平 滑笳線維が一見充実性に発育しているようにみ方，血管 を取り巻く筋線維とそうでない智線維の区別が明らかで ないもので, 充実型 (capillary or solid type) と呼んで いる. 第 2 の型は，血管腔がかなり大きく明瞭で，これ を笳線維が厚く取り巻き,一見静脈の形態を示し, 血 管壁を構成する筋線維と血管の間を錯綜する筋線維が明 らかに区別できるもので, 静脈型 (venous type) として いる，第 3 の型は，血管腔が著明に抎張し，血管腔内に しばしば血液を満たし，血管壁の筋線維がうすく，一見 海綿状血管腫に類似しているもので, これを海綿型 (cavernous type) と名づけている. 本症例は, 組織学 的には，森本の分類による静脈型 (venous type) に近い ものと考えられる.

${\text { Hagy } 5^{7)} \text {, Collins }}^{8)} ら$, McGowan $5^{9)}$, Cherrik $5^{10)}$, Goldblattら ${ }^{11)}$ によると，本腫湐は多くの筋線維を有す る細胞より構成され，その筋線維は，マッンン染色，ア ザン・マロリー染色, P.T.A.H. 染色で陽性を示したと 述べている，本症例も彼らの報告とほぼ同様の結果を示 した.

Reichart (5)の電子顕微鏡学的検索によると,この腫場 の実質は $2 つ の$ 型の細胞, 寸なわち, 紡鍾形の平滑筋様細 胞之，多角形の内皮様細胞から構成されている．前者の 細胞には，多数の筋フィラメントと縹密体，および少量 のミトコンドリアと飲小胞がみられ, 紐胞と周国の間質 との境界には，基底獏㩐造が存在していた。一方，後者 の細胞には,多角形の核と著明な核小体がみられ，莰合し ている細胞膜は隣接細胞とデスモゾーム(desmosome)に よって接合していた。また，ときには管腔侧で少数の短 
い微䄉毛が認められた。われわれの症例 も， Reichart らの所見と同様に平滑筋様細胞と内皮様細胞の 2 つの型 の細胞が認められた。しかしながら，彼らの正例では， 腫瘍は主として内皮様紐胞から成っていると報告してい るが，われわれの症例では，腫瘍は主として平滑筋様細 胞から成っていた。 また，2つの型の細胞以外に，細胞 内の細線維の形態や細胞内の小器官の発達の程度など から，いろいろな細胞も存在していると考劣られた。こ れらの細胞には，血管内皮様細胞あるいは平滑筋様細胞 に分化する可能性のある幼若な細胞も含まれていると思 われた。

本腫瘍の間質についての電子顕微鏡所見の報告はまた みられない。われわれの症例では, 間質の線維芽細胞が 少ないにもかかわらず，平滑筋様細胞の基底膜に接した 間質に，膠原線維が多く認められた。 I血管の平滑笳細胞 は略原線維と弾性線維を産生できるといわれていること から 12), これらの膠原線維は，この腫湯の平滑筋様紐胞 によってつくられたのではないかと考えられた。

光学顕微鏡および電子顕微鏡所見から，本症例は悪性 腫瘍でないことが明らかであった。

本腫瘍は血管壁の平滑筋細胞が増殖してできたもので あるといわれ ${ }^{6,13)}$ ， その発生誘因としては，機械的因子 とェストロゲンの影響が考えられている3． 本症例で は，平滑筋様細胞が腫湐の主体をなしていたが，内皮様 細胞も増殖しており，さらに，これらの 2 つの型に属さ ない細胞すみられたことなどから，本腫瘍の起源に内皮 細胞が関与している可能性もあるかもしれないまた， 血管筋腫は真の脾瘍でなく, 口唇という部位から考えて, 外傷に対する血管組織の一種の反応性の増殖物とも考元 られた，血管筋腫を過誤腫と考えている人もいる1).

\section{ま と め}

本提例の血管朌腫の光学顐微鏡および電子顕微鏡所見 は次のとおりであった。

1. 腫瘍は光顕的には，小血管を囲む組織が結節状に 增殖したもので，血管壁は，エラスチカ・ワンギーソ ン, P.T.A.H. 染色で陽性を示した.

2. 電顕的には，腫湯には血管腔の内面を被嘚する内 皮様細胞と血管壁を構成する平滑䇨様細胞が区別され， 腫瘍は主として後者から成っていた。

3. 内皮様細胞には細胞内小器官がみられたが，それ らの発達は普通であった。しかし，細胞質内の細線維 (fine filament) は豊富であり, 細胞膜周辺部には多くの 飲小胞 (pinocytotic vesicle) がみられた。

4. 平滑筋様紐胞内には, 笳フィラメント（myofila- ment)，緻密体 (dense body) がみられ，その周井に基 底膜が存在していた。

5. 平滑筋様細胞の 外侧の基底膜に接した間質には, 膠原線維が多くみられたが，線維芽細胞はほとんどみら れなかった。

な挹，本論文の要旨は第23回日本口腔外科学会総会に おいて発表した。

\section{引用 文 献}

1) Gutmann, J., Cifuentes, C., Balzarini, M.A., Sobarzo, V., and Vicuña, R.: Angiomyoma of the oral cavity. Oral Surg 38: 2691974.

2) 富田汪助, 永井哲夫, 中村保夫：上唇部に発生 した血管筋腫の 1 例。 日口外誌 24：362 1978.

3) Duhig, J.T., and Ayer, J.P.: Vascular leiomyoma: A study of sixty-one cases. Arch Pathol 68: 4241959.

4) Reichart, P., and Reznik-Schüler, R.: The ultrastructure of an oral angiomyoma. J Oral Pathol 6: 251977.

5) 石川梧朗, 秋吉正豊: 口腔病理学. 永井書店, 京都，1970，996頁.

6）森本典夫：血管筋腫（血管性平滑笳腫）の臨床 病理学的研究. 鹿大医誌 24: 6631973.

7) Hagy, D.M., Halperin, V., and Wood, C.: Leiomyoma of the oral cavity.; Review of the literature and report of a case. Oral Surg 17: 7481964 .

8) Collins, L.R. and Elzay, R.P.: Leimyoma of the oral cavity: report of a case. J Oral Surg 26: 1421968.

9) McGowan, D.A., and Jonas, J.A.: Angioma (vascular leiomyoma) of the oral cavity. Oral Surg 27: 6491969.

10) Cherrik, H.M., Dunlap, C.L., and King, O.H.: Leiomyomas of the oral cavity. Review of the literature and clinicopathologic study of seven new cases. Oral Surg 35: 54 1973.

11) Goldblatt, L.I., and Edesess, R.B.: Central leiomyoma of the mandible. Oral Surg 43: 5911977.

12) Paule, W.J.: Electron microscopy of the newborn rat aorta. J Ultrastruct Res 8: 219 1963.

13) Lucas, R.B.: Pathology of tumors of the oral tissues. $3 \mathrm{ed}$, Churchill Livingstone, New York, 1976, p 229. 